\title{
THE STATE OF SECURITY OF TODAY'S WORLD AFTER 70 YEARS OF THE UNITED NATIONS
}

\author{
Branislav Đorđević \\ Institute of International Politics and Economics, Belgrade \\ Zoran Jeftić \\ University of Belgrade, Faculty of Security Studies \\ Dragan Đoković \\ Cabinet of the Prime Minister of the Republic of Serbia
}

\begin{abstract}
$\Delta$ t a time when the United Nations mark 70 years of its existence, when the leaders of the 193 member states of this world organization adopted, with a lot of faith, a transformative 2030 Agenda for Sustainable Development, the world is faced with many difficult challenges to security.

Effective indicators of contemporary international security, as well as the challenges, risks and threats that reflect it, show that the security of the modern world has been jeopardized, directly or indirectly, in the highest possible degree, since the end of the Second World War.

That is why there is increasing importance of the United Nations, which, with all its drawbacks over the past seventy years, have represented the best model of multilateral cooperation in the field of security and without whose existence the world would have much larger international problems. The efforts this organization makes with the aim to protect and establish peace in the world must be respected, and the contents of the UN General Assembly resolution 59/565 A of 2004, devoted to threats to the international security, should be seen in that light as well.
\end{abstract}

Key Words: international security, the dangers of socio-economic nature, armed conflicts, nuclear, radiological, chemical and biological weapons, terrorism, organised crime

\section{Introduction}

The he relatively predictable nature of international relations has been disrupted by ending of the Cold War, or the termination of the bloc division of the world, so that today's strategic planners must take into consideration a large number of related security issues starting primarily from the globalization as the dominant process in the international community. The common denominator for all concepts of globalization

\footnotetext{
${ }^{1}$ On characteristics of the world during the bloc divisions, look for more details: Branislav Đorđević, the Cold War, the Academy for Diplomacy and Security, Belgrade 2012
} 
refers to the expressed and intensive interaction of political, economic, social and military factors. To be able to adapt to and manage challenges, the governments of all countries were supplied with the requirements for global reviewing and action in a way that was not the case until now.

Security concerns of the modern world are determined by the global trends in the first half of the $21 \mathrm{st}$ century. The world community is and will remain extraordinarily violent with the overall economic development that leads to a widening gap between the rich and poor, among countries and within them. The development of the global economy and its complete interdependence creates new forms of vulnerability and the need for security checks. As a result of its own overstrain the potential of the United States is also being reduced, which by the nature of its own existence was the intent on the monocentric arrangement of the world. Asymmetric warfare, as a result of the inability of opposing western conventional means causes new forms of conflict with the expressed ethnic, religious and racial tensions. The general availability of information technology creates the possibility of launching new forms of a conflict, which, along with the changes in global media coverage may affect the way the military assets are being used.

"In addition, the modern world found itself facing new, previously unknown threats. Among them, the most important are: uncontrolled escalation of the armed conflicts; the global economic crisis; international terrorism; spread of nuclear and other weapons of mass destruction; monstrous increase in drug trafficking; illegal immigration, which occasionally gets the characteristics of slave trade; an incredible increase in trafficking in human organs, and from people kidnapped for that purpose; piracy and software piracy; criminalization of different walks of life and so on. To this, certainly not the final list, should be added the technogenic disasters and environmental problems taking on a planetary character and affecting the general climate change and the deterioration of the quality of human life." ${ }^{2}$

International relations in the post-Cold War era are characterized by a high degree of unpredictability and ambivalence. A wide range of new challenges for nations and peoples has been replaced by military threat security to security. The risk of large scale conventional and nuclear threats has been replaced by the low-intensity challenges, internal and regional conflicts.

Events, that is, processes that result in mass death, decrease of chances for life and which undermine the state, can be seen as a threat to international security. In this regard, the resolution of the General Assembly of the United Nations (UN), A 59/565 in 2004 identified six categories of threats facing the world: (1) economic and social threats, including poverty, infectious diseases and environmental degradation; (2) inter-state conflicts; (3) internal conflicts, including the civil war, genocide and other serious crimes; (4) nuclear, radiological, chemical and biological weapons; (5) terrorism and (6) transnational organized crime. ${ }^{3}$

\footnotetext{
${ }^{2}$ Miroslav Mladenovic, Jelena Ponomareva, China-US-Russia - a global triangle of the 21st century, Sociological Review, Belgrade, YU ISSN 0085-6320, UDK 316.2011, vol. 45, no. 4, p. 460.

${ }^{3}$ A / 59/565 Follow-up to the outcome of the Millennium Summit - Note by the Secretary-General, Dec. 2 2004, That resolution represents, basically, the basis for this work.
} 


\section{The Dangers of socio-economic nature}

Within the entire spectrum of the dangers of socio-economic nature faced by the modern world, the following ones occupy special place by their intensity: (a) poverty, (b) infectious diseases and (c) environmental degradation.

\section{Poverty}

In the last decades of the past century and the beginning of the current millennium, poverty of a large part of humanity has become alarming. Explicit data of the relevant institutions, such as the United Nations through the annual reports on the achievement of the Millennium Development Goals, ${ }^{4}$ the World Health Organization (WHO), the Food and Agriculture Organization of the United Nations (FAO), United Nations Educational, Scientific and Cultural Organization (UNESCO) and others, speak in support of this statement.

In the last decade of the twentieth century, in the developing countries, per capita income increased by an average of three percent per year, while the number of people living in extreme poverty reached a level of 836 million people.

In at least 54 countries, average per capita income declined during the same period. Over 60 countries are in a hopeless "debt bondage" situation.

Some other data show the drastic state of poverty in the world: ${ }^{5}$

- 868 million people are chronically undernourished (FAO 2012),

- 2 billion people lack access to essential medicines,

- 738 million lack safe drinking water (MDG Report 2012),

- 1.600 million does not have adequate housing (UN Special Rapporteur 2005),

- 1.600 million are without electricity (UN Habitat, "Urban Energy"),

- 2.500 million do not have adequate sanitary conditions (MDG Report 2012),

- 796 million adults are illiterate (www.uis.unesco.org), and

- 218 million children (from 5 to 17 years) work as soldiers, prostitutes or servants (mostly in agriculture, construction and textile industries).

Every year, nearly 11 million children die of hunger, and more than half a million women die during pregnancy or childbirth.

The continent that is hardest hit by poverty is Africa. In sub-Saharan Africa, the average life expectancy over the last 20 years was reduced from 50 to 46 years. While in developed countries less than one in 100 children dies before the age of five, in most countries in subSaharan Africa this ratio is one child out of 10 , and in 14 countries, even one child of five.

With the adoption of the Millennium Development Goals, the international community has pledged to significantly reduce poverty by $2015 .^{6}$ Estimates of the impact of the

\footnotetext{
${ }^{4}$ The Millennium Development Goals Report, 2015, which provides a detailed analysis of the situation of poverty in the world, see the official website of the United Nations http://www.un.org/millenniumgoals/news.shtml (12.09.2015.)

${ }^{5}$ The data presented in this part of the paper are taken from the study "The problems of global poverty", by Thomas Poga, the German philosopher and sociologist and professor at the Yale University (www.pescanik.net 26.09.2015.).

${ }^{6}$ Millennium Development Goals consist of eight goals that all United Nations member states have agreed to try to achieve by 2015.
} 
former Millennium Project indicate that 14 percent of the world population still has less than $\$ 1.25$ per day at their disposal to meet the basic needs. ${ }^{7}$

In the area of reducing child mortality rates and achieving an increase in primary education, the world continues to lag behind its commitments. Both poor and rich countries have pledged to take action on social and economic outcomes. Promises have not materialized either in terms of origin or in terms of actions, and long-term liabilities are short-lived.

It is up to us to believe that the goals of mankind defined in the document "Transforming our world: the 2030 Agenda for Sustainable Development" will be placed at the centre of national and international strategies to reduce poverty. ${ }^{8}$ The dramatic lack of financial support for the MDGs in 2000 stipulates that the responsibility for achieving the goals of the new agenda for sustainable development take those who have committed by their policy and good governance to take such goals to the level at which they can be achieved.

For the least developed countries, the assistance of the United Nations Development Program (UNDP) and the Capital Fund of the United Nations Development Program (UNCDF) will be crucial and should be structured in support of the 2030 Agenda for Sustainable Development.

\section{Infectious diseases}

In recent decades, the world has been faced with the emergence of new infectious diseases, the revival of the old ones and the spread of resistance to a growing number of antibiotic drugs. For example, the last polio epidemics in the world threatens to undermine its rapid eradication, which has been the one of the great goals of the 21st century; not to mention Ebola which is still raging in Africa!

Undeniably, the international response to AIDS has been and remains slow and is guided in a shamefully bad way. The first major international initiative against AIDS, known as the "Global Program on AIDS", started in 1987, six years after the first case of a HIVinfected person, and only after millions of people were infected worldwide. Only nine years later, and after 30 million infected, the Joint United Nations Programme on HIV and AIDS (UNAIDS) was developed, whose work is coordinated by the UNAIDS Secretariat.

By 2000, when the Security Council debated for the first time about "Aids" as a threat to international peace and security, the number of deaths per year from HIVIAIDS in Africa surpassed the number of deaths in all the civil wars in 1990.

\footnotetext{
${ }^{7}$ Millennium Development Goals Report 2015, United Nations, New York, 2015, pg 4.

${ }^{8}$ As a result of years of negotiations of all 193 UN member states, the General Assembly of this world organization adopted on 26 September 2015, the document entitled "Transforming our world: the 2030Agenda for Sustainable Development" aimed at the elimination of the biggest problems of the world. The document formulated 17 general and 169 specific targets for their implementation and will require between 3.5 and five billion dollars each year by the year 2030 .

New targets are set according to the eight Millennium Development Goals which were adopted by world leaders 15 years ago, out of which only one was realized - reducing by 50 percent the number of people living in extreme poverty. This is primarily achieved thanks to the economic growth in China.

Three months before the expiry of the previous Millennium Development Goals, one of them was close to achieving - reducing by half the number of people in the world who lack access to clean water.
} 
By 2003, when the Global Fund to Fight AIDS, Tuberculosis and Malaria was founded, in Africa alone there were more than 11 million children whose parents died from HIV.

The fact that Africa is suffering the brunt of the HIV pandemic raises the disturbing question of international responsibility because of the slow response, which led to the fact that by the spread of the disease life expectancy in some African countries dropped to only 30 years.

Progress in the fight against other lethal infectious diseases remains almost negligible. Global control of tuberculosis, which had been almost forgotten among the western public, has shown significant progress, including the improvement of the political obligation of states to provide financing, formulate the strategy and ensure access to medication and medical research. Nevertheless, in 2013, there appeared nine million new cases of TB, where 1.5 million people died. ${ }^{9}$

The World Health Organization estimates that, if current trends continue, by 2020 nearly one billion people will become infected, 150 million people will become carriers of the disease, and as a consequence of the disease 36 million people will die.

Climate changes and the disruption of the ecological balance increase the incidence of diseases, primarily those of zoonotic nature. ${ }^{10}$ In addition to infectious diseases that can get epidemic and pandemic character, real asymmetric threat is also the misuse of biological agents in the form of a potential means of mass destruction. Therefore, the issue of diseases as a security threat is increasingly appearing on the agendas of the security strategy of almost all countries of the world.

\section{Environmental degradation}

Environmental degradation has multiplied the destructive potential of natural disasters and in some cases accelerates their occurrence. The dramatic reproduction of these major disasters that we have witnessed in the last 50 years is cause for concern for the whole world.

More than two billion people have been affected by natural disasters over the last decades, while in the same period the world economy has suffered losses that exceed the level of losses in the previous four decades combined. If climate changes cause even more flooding, fires, droughts and storms, all this can further accelerate economic losses.

Care about the environment is rarely regarded as a factor of safety or development. There is no coherence in the environmental protection efforts on a global level. Many attempts to take over the government structures and create interests in solving global problems of environmental degradation have not effectively been implemented because the climate changes have been ignored, as well as deforestations, droughts and the like. Regional and global multilateral agreements on the environment are undermined by inadequate implementation and enforcement by Member States.

Current trends indicate possible systemic deterioration of the people's nutrition in many countries, especially in sub-Saharan Africa. Population growth in the developed world and increased consumption per capita in the world of industrialized countries, have led to greater demand for the already scarce food resources.

\footnotetext{
${ }^{9}$ Global Tuberculosis Report 2014, World Health Organization, New York, 2015, pg. xi.

${ }^{10}$ Zoran Jevtic, Vanja Rokvic, Elizabeta Ristanovic, The Role of the Serbian Armed Forces in Humanitarian Health Action and Fight Against Biological Threats, The Review of International Affairs, January-March 2015, p. 75.
} 
The lack of arable land, water shortages, excessive catching of fish, deforestation and changing ecosystems are daunting challenges for sustainable development. It is expected that the world population will increase from the current 7.2 billion to 9.6 billion people by 2050 , with about such an increase in the countries that are the least prepared to handle it. ${ }^{11}$ Providing food for the rapid growth of the population will be possible only if a significant increase of agricultural production is achieved.

Finally, when it comes to economic and social problems, it should be noted that international institutions and states are not organized nor equipped so as to solve all the arising problems in a coherent and integrated manner.

In 2002, world leaders agreed at Monterrey that aid donors and recipients of assistance should mutually be obligated to achieve development and progress. ${ }^{12}$ The primary responsibility for economic and social development lies with the governments, which must create a conducive business environment for stronger private sector development and effective assistance through stable economic policy.

In addition to substantial improvement of policy and institutions in developing countries, donor countries have agreed to renew their efforts to reduce poverty, including the reduction of trade barriers, increasing development assistance and debt relief for highly indebted poor countries.

However, the problems remain. Some advanced industrialized nations are on track to meet their Kyoto targets for reasons outside the field of climate policy, such as, for example, a reduction in their industrial production. The United States, accounting for about one-quarter of the world's greenhouse gas emissions, still refuses to ratify the Protocol. ${ }^{13}$

At the same time, some the developing countries, which account for only $1 / 10$ of these greenhouse gas emissions, also oppose this Protocol as binding, because the allocation of funds for the purchase of expensive filters or purification are considered to be a direct limiting factor to their economic growth.

\section{Inter-State Conflicts}

After the Second World War, the world was faced with interstate wars which took many victims. According to data of "The Polynational War Memorial," after the Second World War, there were 248 wars in the world that were waged or are still being waged, 179 of which are interstate. ${ }^{14}$ It is estimated that over 23 million people were killed in these wars, with the number of troops accounting for $10-15$ percent, and $85-90$ percent are civilians. ${ }^{15}$

\footnotetext{
${ }^{11} \mathrm{http}: / /$ balkans.aljazeera.net/vijesti/indija-pretice-kinu-po-broju-stanovnika (10.19.2015).

${ }^{12}$ More details on the International Conference on Development held in Monterrey (Mexico), 18-22. March, 2002, see: Monterrey Consensus of the International Conference on Financing for Development, United Nations, New York, 2003.

${ }^{13}$ The Kyoto Protocol to the United Nations Framework Convention on Climate Change is an international agreement on climate change, signed to reduce emissions of carbon dioxide and other gases that cause the greenhouse effect. The Protocol entered into force on 16 February, 2005, when it was ratified by Russia. Serbia has accepted the Kyoto Protocol on 24 September 2007. States that have ratified it amount to 61 percent of pollutants.

${ }^{14}$ www.war-memorial.net/wars_all.asp (23.09.2015).

15 William H. Wiist, et al., "The Role of Public Health and the Prevention of War: Rationale and Competencies", American Journal of Public Health, Vol. 104, No. 6, June 2014, New York, pp. 34-47.
} 
It is extremely worrying that the relationship between the dead soldiers and civilians in wars since 1945 is about 1:7, while in the Second World War the ratio was 1:1.35, i.e. of total of 48.2 million dead, 20.8 million were soldiers and 27.4 million civilians. ${ }^{16}$

Although the data presented give warning signs to humanity and compel the modern world for urgent action in stopping arms stockpiling, exactly the opposite happens. The renowned Stockholm International Peace Research Institute (SIPRI) has come to an indicator that the total allocation for defence at world level in 2014 amounted to 1.776 billion dollars, which is higher than spending on health care or education. ${ }^{17}$

It is more than obvious that "on the one hand, the military industrial complex of the countries of the "centre" is strongly involved in the main world economic developments, and on the other, it represents one of the most thorough pillars of global power politics. The main formula of modern military application component in the process of globalization is: the application of modern technology of war, with a strong instrumentalization of international organizations and institutions. History of wars is characterized by two important, apparently contradictory characteristics. The first refers to the fact that humanity, moving away from the biological prehistory, has increasingly been characterized by destructiveness and, second, that the more man became more sensible and aware, the war has become more comprehensive in terms of number of people involved, and by the amount of social subsystems it included." ${ }^{18}$

According to the "SIPRI Yearbook" for 2015, the share of defence costs in the global gross domestic product in 2014 was 2.3 percent, total defence spending globally per capita in 2014 amounted to 245 dollars, and countries with the highest defence costs are the United States (610 billion dollars), China (216 billion dollars), Russia (84.5 billion), Saudi Arabia ( 80.8 billion dollars) and France ( 62.3 billion dollars). ${ }^{19}$

According to the Global Peace Index (GPI), as an indicator of the relative state of peace in 162 countries, produced every year by the Institute for Economics and Peace with offices in Sydney, New York and Mexico City, only in 2014 there were more wars than in any other year since 2000. Countries with the highest levels of peace are: Iceland, Denmark, Austria, New Zealand and Switzerland, the countries with the lowest levels of peace are: Somalia, Iraq, South Sudan, Afghanistan and Syria. ${ }^{20}$

When it comes to inter-state wars, it is interesting to draw a parallel between the period of "Cold War" and the modern world.

In the period of "Cold war", basic characteristics of inter-state wars were: (a) anticolonial (national liberation) wars; (b) conventional military interventions by major world or regional powers; and (c) the armed conflicts between independent and sovereign states (mainly in Asia and Africa).

During this period, the most common causes of inter-state wars were: (a) the interests of the colonial powers; (b) neo-colonial interests of conquering energy and raw

\footnotetext{
${ }^{16} \mathrm{http}: / /$ warchronicle.com/numbers/WWII/deaths.htm (24.09.2015).

${ }^{17} \mathrm{http}: / /$ www.sipri.org/yearbook/2015 (24.09.2015).

${ }^{18}$ Miroslav Mladenovic, Zoran Jeftic, Political changes and their impact on security and strategic defence concepts, Vojno delo, autumn/2012, Belgrade, p.138.

${ }^{19} \mathrm{http}: / /$ www.sipri.org/yearbook/2015 (24.09.2015).

20 "Global Peace Index Report 2015", www.visionofhumanity.org/\#/page/our-gpi-findings (25.09.2015.).
} 
material resources on someone else's territory; (c) the hegemonic policy of spreading and imposing ideologies and models of social development; (d) the interests of the military-industry complexes, and (e) the consequences of an unjust colonial heritage.

\section{Internal conflicts - civil wars}

Civil war can be seen as the armed conflict between the class, ethnic, political or other antagonistic social groups within a single country to achieve certain political and economic goals. It occurs as a result of accumulated and unresolved social, economic, political and other contradictions in society.

After World War II, 248 wars were waged or are being waged in the world, of which number 69 represent the internal conflict, or civil war.

According to the analysis of the reputable "National Geographic", there are currently 12 active conflicts conducted in the world, that take more than 1,000 victims a year, making them wars, according to the characterization of the United Nations. In addition, many minor skirmishes are also taking place in the world. Most of the currently "live" wars last between three and ten years, several of them started last year, and there are conflicts like the war, which has lasted for more than 60 years. The wars that are currently waged are of an average duration of 8.8 years, which is comparable to the average of wars over the past 120 years.

Most current wars are being waged now in Africa. On the black continent, wars are waged in Somalia, Nigeria, Sudan, Central African Republic, Libya and Egypt. In Asia, the ongoing wars are in Israel, Afghanistan, Pakistan, Syria, Yemen and Iraq. In America, there is currently war with the cartels in Mexico, while in Europe, the war in Ukraine has started.

In 2014, wars took about 40,000 victims, mostly in Syria, where more than 28,000 people were killed only in the last year, out of the total of 270,000 victims of this civil war so far. ${ }^{21}$

Some of the general features, characteristics and consequences of intergovernmental conflicts/wars waged after the Second World War are the following: (a) millions of victims, especially among the civilian population; (b) high level of brutality and cruelty; (c) genocide; (d) ethnic cleansing; (e) mass movements of refugees; (f) extremely difficult humanitarian taking care of the innocent victims, etc.

The largest number of victims in internal conflicts occurred in Rwanda in 1994. Officials of the UN Secretariat had failed to submit to the Security Council a timely warning of extremist plans to kill thousands of members of the Tutsi and moderate members of the Hutu tribe. When the genocide began, the number of "blue helmets", who were engaged in that country, was reduced to only 270 people, and the UN Security Council and the UN, due to pressure from the US, failed to respond. The result is almost $1,100,000$ victims!

All these conflicts are resolved or will be resolved by negotiating security, which has the extremely complex nature, and "the reasons for this are numerous, and range from a state of absolute animosity and frustration manifested by the parties to the conflict, to the lack of rational thinking and the existence of extreme euphoria and high expectations." ${ }^{22}$

\footnotetext{
${ }^{21}$ In http://www.nationalgeographic.rs/vesti/3405-rat.html (28.09.2015).

22 Željko Ivaniš, Miroslav Mitrovic, Miroslav Mladenovic, "Conflict Resolution in the Western Balkan countries through negotiation," Proceedings of the Seventh International Congress on 'Ecology, Health, Work and Sport', Banjaluka, 21-23.05.2015, str. 292.
} 


\section{Nuclear, radiological, chemical and biological weapons}

Nuclear, radiological, chemical and biological weapons pose a significant threat to international security, primarily due to potentially high number of victims they can cause, but also because of difficulties in their timely detection.

\section{Nuclear weapons}

Any use of nuclear weapons, accidentally or intentionally, leads to human casualties and economic disruption of catastrophic proportions. The threat of nuclear proliferation the spread of nuclear weapons among States - is being increased in two ways.

According to the UN General Assembly Resolution A 59/565, the report of the Highlevel Panel on Threats, Challenges and Change, entitled "A more secure world: our shared responsibility", the first and most immediate concern is that some countries, under cover of their current Treaty on the Non-Proliferation of Nuclear Weapons membership, will covertly and illegally develop full-scale weapons programmes, or that acting within the letter but perhaps not the spirit of the Treaty - they will acquire all the materials and expertise needed for weapons programmes, with the option of withdrawing from the Treaty at the point when they are ready to proceed with weaponization.

The second longer-term concern is about the erosion and possible collapse of the whole regime of the Treaty on the Non-Proliferation of Nuclear Weapons. Almost 60 States currently operate or are constructing nuclear power or research reactors, and at least 40 possess the industrial and scientific infrastructure which would enable them, if they chose, to build nuclear weapons at relatively short notice if the legal and normative constraints of the Treaty regime no longer apply. ${ }^{23}$

The fact is that sixty years after the first atomic bombs exploded in Japan, the world has never been more indifferent, and that along with it, the total power of the world's nuclear arsenal has never been greater. When in August 1945 the first atomic bombs were dropped on Japan, the explosion in Hiroshima had the power of the explosion of 15,000 tons of ordinary TNT explosives (15 kilotons) and the explosion in Nagasaki amounted to 20 kilotons. According to optimistic estimates, the total world nuclear arsenal comprises of 3,000 megatons of TNT, the equivalent of 150,000 bombs dropped on Nagasaki. Less optimistic estimates indicate that the arsenals of the nuclear powers stockpiled nuclear weapons with a total output of about 15,000 megatons, which is on par with the 750,000 bombs in Nagasaki that killed 70,000 people in one second. ${ }^{24}$

Treaty on the Non-Proliferation of Nuclear Weapons has become less and less effective. ${ }^{25}$ In addition to the "old" nuclear powers, some other, often politically aggressive countries, have

\footnotetext{
${ }^{23}$ A / 59/565 Follow-up to the outcome of the Millennium Summit - Note by the Secretary-General, Dec. 22004 pg. 7.

${ }^{24}$ Slobodan Bubnjević, Post Nuclear era: Deadly Arsenals, "Vreme", 10 November 2005.

${ }^{25}$ Nuclear Non-proliferation Treaty (NPT) entered into force in 1970. The treaty defines the status of nuclear and non-nuclear states. Countries without nuclear weapons pledged not to develop these weapons, and countries in possession of nuclear weapons committed themselves not to sell them to other countries, nor to sell technology for its production. International Atomic Energy Agency (IAEA) based in Vienna implements control measures of the Treaty on the Non-Proliferation of Nuclear Weapons.
} 
nuclear weapons nowadays. According to the International Peace Research Institute in Stockholm, at present, nine countries possess nuclear weapons, and these are: Russia $(7,500$ warheads - w/h), USA (7,260 w/h), France (300 w/h), China (260 w/h), Great Britain $(215 \mathrm{w} / \mathrm{h})$, Pakistan (100-120 w/h, India (90-110 w/h), Israel (80 w/h and North Korea $(6-8 \mathrm{w} / \mathrm{h}) .^{26}$

To date, 189 countries joined the Treaty on the Non-Proliferation of Nuclear Weapons. India, Pakistan and Israel have not acceded to the Treaty. ${ }^{27}$

Regardless of whether more states acquire nuclear weapons, there are also grave risks posed by the existence of large stockpiles of nuclear and radiological materials. According to data of IAEA, 1,300 kilograms of highly enriched uranium exist in research reactors in 27 countries. ${ }^{2}$

The total volume of HEU stockpiles is far greater, and many HEU storage sites are inadequately secured. States have publicly confirmed 20 cases of nuclear material diversion and more than 200 incidents, involving illicit trafficking in nuclear materials, which have been documented over the past decade. ${ }^{29}$

\section{Radiological weapons}

Radiological weapons are to some extent a different kind of threat than nuclear weapons, because they are more weapons of mass disruption than of mass destruction.

A radiological weapon attack is easier to accomplish than a nuclear attack, due to the relatively easy way of designing and using these types of weapons of mass destruction. Using biological and chemical weapons requires greater knowledge than the knowledge of radiological weapons.

It is therefore not surprising that certain terrorist groups have expressed interest in radiological weapons.

Radiological weapons can use plutonium or highly enriched uranium but can rely simply on radioactive materials of which there are a number of sources used in medical and industrial facilities worldwide.

Radiological weapons are primarily the weapons of "mass confusion" rather than weapons of "mass destruction". ${ }^{30}$

Currently, the destructive effect of a radiological or "dirty" bomb does not exceed the effect of a bomb with conventional explosive, and even the radiation effects of such a bomb are likely to be limited, but the psychological impact is much greater.

The subsequent harmful effects would follow - from the disruption and economic damage, through mass panic and the necessity of evacuating and decontaminating the affected areas. The ubiquity of radiological materials and the requirements for simple manufacture of detonators of such devices suggest a high likelihood of their use.

\footnotetext{
${ }^{26}$ http://www.sipri.org/yearbook/2015 (24.09.2015).

${ }^{27}$ For South Sudan, the newest, 193 UN member state, there is no information on whether it joined the Treaty on the Non-Proliferation of Nuclear Weapons.

${ }^{28}$ Atoms for peace and development, Vol. 56-1, International Atomic Energy Agency, Vienna, 2015, pg. 5.

${ }^{29}$ A / 59/565 Follow-up to the outcome of the Millennium Summit - Note by the Secretary-General, Dec. 22004 pg.

${ }^{30}$ Michael A. Levi and Henry C. Kelly, "Weapons of Massive Disruption" Scientific American, November 2002, pp. 71-81.
} 
According to the report of the International Atomic Energy Agency since 2009, states have confirmed 1,562 incidents, which were related to unauthorized possession, theft, loss and unauthorized use of radioactive materials. ${ }^{31}$

Finally, the most effective response in the event of radiological terrorism is to educate the population. An effective response to a radiological attack requires "... a system that is able to quickly assess the extent of the damage, identify appropriate treatment, develop a coherent plan of action and bring the emergency services very quickly on the scene. ${ }^{32}$

\section{Chemical and biological weapons}

Chemical and biological materials also pose a growing threat to the modern world. Together with nuclear weapons they represent a huge potential, which could be used in a one-sided attack for causing mass casualties. Chemical agents are widely used and relatively easy to acquire and weaponize.

There are about 6,000 industrial chemical facilities worldwide, posing potential targets and opportunities for the acquisition of materials. States are reluctant and late with the destruction of chemical weapons scheduled by the Chemical Weapons Convention ${ }^{33}$ : of the 70,000 tons of chemical poisons known, the Organization for the Prohibition of Chemical Weapons (OPCW) has so far verified the destruction of only 9,600 tons. $^{34}$

Today, apart from the possibility that biological weapons are applied in interstate conflicts, there is a much greater risk that they could be used by various terrorist organizations, sects and individuals. The risk of use of biological weapons is increasing due to the existence of a large number institutionalized, non-institutionalized and microbiological laboratories whose work cannot always be offered full insight, simple production of certain biological agents and the wide availability of scientific information through professional publications and the Internet.

Biological weapon is usually applied covertly and insidiously, because it is invisible, colourless, odourless and tasteless, and cannot be detected by the senses, and it is even difficult to detect it by instruments. It has the ability to endanger people, animals and crops on a much larger ground expanse than other weapons, so it is called the "weapons of spatial effect."

\footnotetext{
${ }^{31}$ www.ns.iaea.org/downloads/security/itdb-fact-sheet-2009.pdf. (26.09.2015).

${ }^{32}$ Danijela Tufegdžić, Radiological weapons as a means of terrorism, "Journal of Security", no. 3, Center for Security Studies, Belgrade, 2010, p. 220.

${ }^{33}$ Chemical Weapons Convention (CWC) is a global agreement on the control of chemical weapons. The Convention entered into force in 1997 when formally began the work of the Organization for the Prohibition of Chemical Weapons (OPCW), which is the executive body of the Convention and is not bound by the UN, and its seat is in The Hague, Netherlands. In accordance with the provisions of the Convention, all countries that have declared to possess chemical weapons were committed to destroy it. The Convention also has provisions for the systematic evaluation of chemical and military installations, as well as for the investigation of allegations of use and production of chemical weapons based on intelligence from other Member States. By August 2010, 188 States have signed the Convention.

${ }^{34}$ A / 59/565 Follow-up to the outcome of the Millennium Summit - Note by the Secretary-General, Dec. 2 2004 pg.13.
} 
According to some data, nuclear weapons are effective up to $300 \mathrm{~km}^{2}$, chemical weapons up to $60 \mathrm{~km}^{2}$ and biological ones can affect the territory of up to $100,000 \mathrm{~km}^{2}{ }^{35}$

The greatest risks of possible use of chemical and biological weapons are: (1) huge and still undestroyed stockpiles of BW and CW (about 70,000 tons); (2) large and hard to control possibilities of relatively simple production of these weapons (in the world there are more than 6,000 chemical production facilities; (3) Highly portable and extremely difficult to detect; (4) The almost unlimited possibilities for use; (5) the effects of the mass destruction of the population, etc.

\section{Terrorism}

Terrorism threatens the values that lie at the core of the United Nations Charter: respect for human rights, the rule of law, rules of war that protect civilians, tolerance among peoples and nations, and the peaceful resolution of conflicts.

The act of terrorism is different from any other act of violence on the following elements: (a) political, religious, ethnic or social motivation; (b) the message that creates an atmosphere of fear, terror, mistrust, or defeatism, and (c) the public disclosure of such an act and the organization behind it. ${ }^{36}$

Terrorism is fed in environments of despair, humiliation, poverty, political oppression, extremism and human rights abuse; it flourishes in contexts of regional conflict and foreign occupation and the inability of a State to maintain public order and peace.

The world war against terrorism which, under the leadership of the US, began after the terrorist attacks on the US on 11 September 2001, did not bring the expected results. The regimes in Iraq and Afghanistan, under military pressure from the US and its allies, quickly succumbed, but not the bearers of terrorism in these countries. It is safe to say that the military action in Afghanistan and Iraq caused the overflow of terrorists outside the borders of these countries, into Syria, Pakistan...

After a relatively brief lull in recent years, terrorism is gaining momentum. According to the annual report on global terrorism of the State Department, ${ }^{37}$ the number of terrorist attacks around the world increased by 35 percent between 2013 and 2014 and total fatalities in them as much as 81 percent. The report states that in 2014 about 33,000 people were killed in nearly 13,500 terrorist attacks worldwide. By comparison, in 2013, 10,000 terrorist attacks resulted in about 18,000 deaths. The number of abductions rose from 3,137 in 2013 to 9,428 in 2014.

As for the large increase in total fatalities, the US State Department connects it with the fact that they were generally individually more lethal. Only in 2014, there were 20 attacks that killed more than 100 people, compared to only two such terrorist attacks in 2013. Just a year earlier, there were 18,000 deaths as a result of 10,000 terrorist attacks.

\footnotetext{
${ }^{35}$ www. server.medfak.ni.ac.rs/Lectures, Medicine/Epidemiology/ (28.09.2015).

${ }^{36}$ Andreja Savic and Ljubomir Stajić, Fundamentals of Civil Security, Faculty of Law and Business Studies, Novi Sad, 2007, p. 159.

${ }^{37}$ See: State Department: Number of terrorist attacks by 35 percent higher in 2014 (http://www.blic.rs/Nesti/Svet/569067, 23.09.2015.), and An increased number of terrorist attacks in the world http: //rs.n1info .com / a70441 / Svet / Svet (23.09.2015.)
} 
In 2014, there were 20 attacks that killed more than 100 people and just a year earlier there were two such attacks. Terrorist attacks took place in 95 countries in 2014, but they were concentrated in the Middle East, South Asia and West Africa. Iraq, Pakistan, Afghanistan, India, Syria and Nigeria account for about 80 percent of all fatalities due to terrorist attacks.

The increase in the number of abductions is mainly attributed to the mass kidnappings done by terrorists in Syria, and above all, the extremist Islamic State and Al Nusra Front, linked to Al Qaeda.

In Nigeria, Boko Haram is probably responsible for all cases of kidnapping, and in 2014 there were about 1,300 such cases, including the famous kidnapping case of almost 300 students from Chibok.

A year earlier, in Nigeria, there were fewer than 100 kidnappings linked to terrorist activities. The State Department report indicates that the Islamic State in 2014 occupied areas of Iraq and Syria that were "unprecedented". The organization added, continues to demonstrate the ability to recruit foreign fighters, and there are self-proclaimed subsidiaries in Libya, Egypt and Nigeria.

The Islamic State is considered responsible for the highest number of deaths in the terrorist attacks of 2014, followed by the Taliban, Somali militant group Al-Shabab and the Nigerian Boko Haram.

Finally, only in one day, on 26 June 2015, in three attacks in France, Tunisia and Kuwait, Islamists killed dozens of people, spreading fear of the strengthening of jihadism. After the attack on the US gas company near Lyon, a headless body of a man was found in the factory premises. Several people were injured. On the beach in Sousse, Tunisian attackers opened fire and left behind 28 victims. A suicide bombing that took place at a Shia mosque in Kuwait has killed "at least 25 " of believers.

The attacks of terrorists on four continents in the last fifteen years showed that AlQaeda, the Islamic State, AI-Shabaab, Boko Haram and groups that joined represent a universal threat to the modern world. ${ }^{38}$

Modern terrorism is not conducted only by one man or one political regime, nor it is, of course, a religion. Today's terrorism represents a premeditated violence that is politically motivated and is mainly aimed at civilian (non-military) targets by terrorist groups or individuals. Those who apply terrorism, regardless of their secular or religious goals, seek to undermine the rule of law and to impose change through violence and fear. Terrorism involves, roughly speaking, plenty of sensation, which is best evidenced by the executions carried out by the Islamic State.

Some of the problems the modern world has been facing in countering terrorism are: (a) many countries have not yet acceded to the international conventions; (b) insufficient financial funds for the functioning of the aforementioned subsidiary bodies of the Security Council and the assistance to States for the implementation of their Antiterrorism Assistance Program; (c) the lack of a single definition of terrorism; (d) existence of double standards and standards in the approach to terrorism, etc.

\footnotetext{
${ }^{38}$ Boko Haram is an Islamic extremist group based in the north-east Nigeria, and is also active in Chad, Niger and Cameroon. It is estimated that it numbers between 7,000 and 10,000 fighters. The group initially had links with AlQaeda, but in 2014 it expressed support for an Islamic State affiliated Harakat Al-Shabab Al-Mujahideen, also known as Al-Shabab, the jihadist terrorist group based in Somalia. Al-Shabaab forces are estimated at 7,000 to 9,000 people.
} 
It should be noted that the world organization has not yet reached an agreement on the notion of terrorism, that is, of defining terrorism. Even five years were to pass after the terrorist attacks on the United States to adopt the United Nations Global CounterTerrorism Strategy). ${ }^{39}$

The United Nations Global Counter-Terrorism Strategy includes: ${ }^{40}$

(a) Deterrence, by transforming causes and seeds of terrorism, by promoting social and political rights, the rule of law and democratic reform; abolition of occupation and respecting the key political objections; the fight against organized crime; reducing poverty and unemployment; and stopping the disintegration of the country;

(b) Determined action against extremism and intolerance, particularly through education and encouraging public debate;

(c) Development of better instruments for global cooperation countering terrorism in a legal framework, which includes respect for civil liberties and human rights, including here also the domain of restriction of rights; exchange of information; and financial control;

(d) Building the capacity of countries to prevent terrorists' recruitment and operations;

(e) Control of dangerous materials and the protection of public health.

In addition, several United Nations conventions for combating terrorism established important normative bases. However, too many countries have remained outside the conventions; many of them have not ratified them, but have continued to adopt internal coercive measures.

\section{International Organized Crime}

International, i.e., transnational organized crime is a threat to the state and society, which threatens the security of individuals and the basic obligations of the state to ensure public order and peace. ${ }^{41}$

Combating organized crime serves the double aim - to reduce this direct threat to the security of the state and the people, becoming a necessary step in the prevention and resolution of internal conflicts, combat the spread of weapons and prevent terrorism. The most common forms of manifestation of transnational organized crime are: drug trafficking, corruption, illicit trafficking in arms and human trafficking.

Drug trafficking is one of the main activities of organized criminal groups having serious security implications. It is estimated that drug trafficking is the main source of income for criminal organizations, which brings them every year, between 300 and 500 billion dollars.

In some regions, the huge profits, realized by this activity, reach a level equal to the gross-product of some countries, which threatens the authority of the state, economic development and the rule of law.

\footnotetext{
${ }^{39}$ After lengthy discussion, the UN General Assembly resolution A / RES / 60/288, adopted on 8 September of 2006, the Global Strategy for Combating Terrorism.

${ }^{40} \mathrm{http} / / / \mathrm{www} . u n . o r g / e n / t e r r o r i s m /$ strategy-counter-terrorism.shtml (15.10.2015).

${ }^{41}$ More details about international organized crime see in monographs: Stajić Ljubomir, Basic Security Publishing House "Draganić", Belgrade, 2006, p. 164-177. Ljubomir Stajić and Radoslav Gaćinović, Introduction to Security Studies, Draslar partner, Belgrade, 2007, p. 282-307.
} 
The narcotics trade has resulted in an increase in intravenous heroin use, which in some areas contributed to the alarming spread of the HIV virus. There are increasing indications of a link between the financing of terrorist groups and income from the opium trade, which is most evident in Afghanistan.

According to the United Nations Office on Drugs and Crime (UNODC) report of 2014: ${ }^{42}$

- Every year, organized crime around the world brings in 870 billion dollars on the basis of illegal activities such as drug trafficking, counterfeiting, arms sales and smuggling of migrants.

- Criminal groups make around 320 billion dollars a year selling drugs, 32 billion dollars on the sale of "white slavery" and about seven billion dollars smuggling of migrants.

- Illegal felling of trees in Southeast Asia alone annually brings in around three and a half billion dollars, and the illegal sale of ivory around $\$ 75$ million.

- Members of organized crime earn about 250 billion dollars each year due to counterfeiting in all areas.

In addition, the estimate of revenues from transnational organized crime ranges from $\$ 500$ billion a year, and even up to 2,100 billion dollars per year, which is 3.6 percent of world gross domestic product. ${ }^{43}$ In the European Union, revenues from organized crime reach 110 billion a year. ${ }^{44}$ Does this information need any comments?

Corruption is one of the newer, more widespread challenges and threats to international security (links of organized crime and members of the state apparatus), which is more encouraged by the lack of cooperation between countries and bad coordination of international organizations.

More than half of the UN member states have not yet signed or ratified the UN Convention of 2000 against Transnational Organized Crime and its three protocols, ${ }^{45}$ as well as the UN Convention against Corruption ${ }^{46}$ in 2003 , nor did they provide the necessary resources for monitoring the implementation of these conventions and protocols.

In 2000, the laundered sum of money amounted to between 500 and 1,500 billion US dollars. Despite the scope of these sums and their role in the maintenance of organized crime, many States do not regulate money laundering. Systematic use of bank accounts secrecy and an increasing number of financial havens remain a serious obstacle in solving this problem.

Most heinous form of organized crime is human trafficking, and all countries in the world should take decisive actions to eliminate it. UN member states should sign and ratify the Protocol to prevent, suppress and punish Trafficking Persons, especially women and children, and parties to this Protocol should take all necessary measures for its effective implementation. ${ }^{47}$

\footnotetext{
42 UNODC Annual Report 2014, UNODC, Vienna, 2015.

${ }^{43}$ Global crime makes 2.100 billion dollars, "Politika", 25.04.2012..

${ }^{44}$ http://www.rtrs.tv/vijesti/vijest.php?id=145214 (14.09.2015).

${ }^{45}$ The United Nations Convention against Transnational Organized Crime and its protocols, was adopted in Palermo from 12 to 15 December 2000. The Federal Republic of Yugoslavia ratified the Convention on 22 June 2001.

${ }^{46}$ The United Nations Convention against Corruption, adopted in the UN General Assembly on 31 October, 2003. Resolution no. 58/4. The State Union of Serbia and Montenegro ratified the Convention in 2005.

${ }^{47}$ Protocol to Prevent, Suppress and Punish Trafficking in Persons, especially Women and Children is the first international instrument of a universal character which contains a definition of trafficking. States Parties are required to include in their criminal legislation or introduce the crime of human trafficking and its various forms (the attempt, complicity, organizing and directing other persons to commit an offense of human trafficking). The purpose of the
} 
States and international organizations have reacted too slowly to the threat of organized crime and corruption. Statements about the seriousness of these threats were rarely observed and appropriate actions taken. The three main factors that hinder the international response to be more efficient are: insufficient cooperation among States, weak coordination among international agencies and non-performance of obligations by many countries. Certainly, we should not poor coordination between international agencies and non-performance of obligations by many countries. Certainly, we should not overlook complicity of organized crime with "... national, political, economic and financial subjects." ${ }^{48}$

The fight against different forms of organized crime is being conducted with variable success. The fight against corruption is suffering due to lack of determination and ignorance of corruption types, its level, area and costs of corruption. In an effort to curb the supply of narcotics, in some countries were registered successes but these are often annulled by failures in others. The efforts of industrialized countries for decreasing of demand have proved to be ineffective and the total number of drug opium and heroin users has remained relatively stable during the last 20 years.

Finally, in some cases, shortcomings in terms of fulfilment of obligations, lead to limiting the ability of states. To remove these problems, international organizations, among which, above all, the UN Office on Drugs and Crime in Vienna, established a program of technical assistance and training, related to the establishing of public order enforcement and effective judicial institutions.

However, the necessary resources for the implementation of these activities are insufficient. The Organization of the United Nations should establish an effective mechanism to help countries to strengthen their capacity in the field of rule of law. Regional organizations and multinational financial institutions should, in this area, provide an active contribution.

\section{Concluding remarks}

The globalization as a process of uniting the world in which social and inter-state relations become increasingly intense, gave birth to new security threats and also drifted towards nonmilitary and asymmetric threats, made them totalitarian, and subsequently made requirements for global security cooperation, where the United Nations has an irreplaceable role.

The UN General Assembly, with a positive role in resolving international problems, often loses its vitality and fails to effectively solve issues put before it. More concentrated work plans that focused on contemporary challenges and threats, as well as more efficient and more clearly defined role for committees of the General Assembly may contribute that the proposed resolutions be harmonized and implemented in a more qualitative and efficient way.

Everything done to reform the UN should create a framework for contemporary international relations and opposition to new security threats. Therefore, the insistence of the UN General Assembly on the continuous monitoring of security threats in the international community, from social to economic and transnational organized crime has its full meaning. The idea of universal

Protocol is to prevent and combat trafficking in human beings as well as protecting and assisting victims of trafficking, with particular insistence on the full respect of their human rights. The Protocol entered into force on 25 December 2003 and has 152 Contracting Parties (151 countries and the European Union). The Republic of Serbia has ratified the Protocol on 6 September 2001, which began to have effect on 25 December, 2003.

${ }^{48}$ Mićo Bošković, Transnational Organized Crime, Police Academy, Belgrade, 2003, p. 24. 
peace and cooperative security based on cooperation is far from attainable reality and the UN have its own strategy based on the Huntington thesis that the paradigm of a harmonious world is too far from reality. It also needs to start from the known position that the UN were not created to introduce the world into heaven but that the world would avoid hell.

Finally, founded with the intention that co-operation between countries replaces the weapons, over the past seven decades the UN have achieved outstanding results in all areas of its operation, but at the same time, they faced a number of challenges, roadblocks in its work, non-compliance with decisions of the Security Council or the General Assembly, and actions of some countries without any compliance with the world organization. At the beginning of the 21 st century, when the world is qualitatively different from the 1945, United Nations are faced with very serious challenges, risks and threats, including the special place of socio-economic problems and security breaches in the world.

The security of the modern world is certainly dramatic, but it is precisely this state that is a warning alarm to the whole world to be united around the idea of development, which is the only way to solve the accumulated problems of mankind. In this regard, the United Nations has the primary role.

\section{References}

[1] A / 59/565 Follow-up to the outcome of the Millennium Summit - Note by the SecretaryGeneral, Dec. 22004.

[2] Atoms for peace and development, Vol. 56-1, International Atomic Energy Agency, Vienna, 2015.

[3] Mićo Bošković, Transnational Organized Crime, Police Academy, Belgrade, 2003.

[4] Branislav Djordjevic, the Cold War, the Academy for Diplomacy and Security, Belgrade 2012.

[5] Radoslav Gaćinović, Contemporary terrorism, Grafomark, Belgrade, 1998.

[6] Global Tuberculosis Report 2014, World Health Organization, New York, 2015.

[7] Zoran Jeftic, Vanja Rokvić, Elizabeth Ristanović, The Role of the Serbian Armed Forces in Humanitarian Health Action and Fight Against Biological Threats, The Review of International Affairs, January-March 2015.

[8] The Monterrey Consensus of the International Conference on Financing for Development, United Nations, New York, 2003.

[9] Millennium Development Goals Report 2015, United Nations, New York, 2015.

[10] Miroslav Mladenovic, Jelena Ponomareva, China-US-Russia - a global triangle of the 21st century, Sociological Review, Beograd, vol. 45, no. 4. 2011.

[11] Miroslav Mladenovic, Zoran Jeftic, Political changes and their impact on security and strategic concept of defense, development work, Vojno delo, autumn / 2012, Belgrade.

[12] Andreja Savić and Ljubomir Stajić, Fundamentals of Civil Security, Faculty of Law and Business Studies, Novi Sad, 2006.

[13] Ljubomir Stajić, Basic Security, Publishing House "Draganić", Belgrade, 2006.

[14] Ljubomir Stajić i Radoslav Gaćinović, Introduction to Security Studies, Draslar partner, Belgrade, 2007.

[15] Željko Ivaniš, Miroslav Mitrovic, Miroslav Mladenovic, "Conflict Resolution in the Western Balkan countries through negotiation," Collection of papers of the Seventh International Congress on 'Ecology, Health, Work and Sport', Banjaluka, 2015.

[16] UNODC Annual Report 2014, UNODC, Vienna, 2015. 